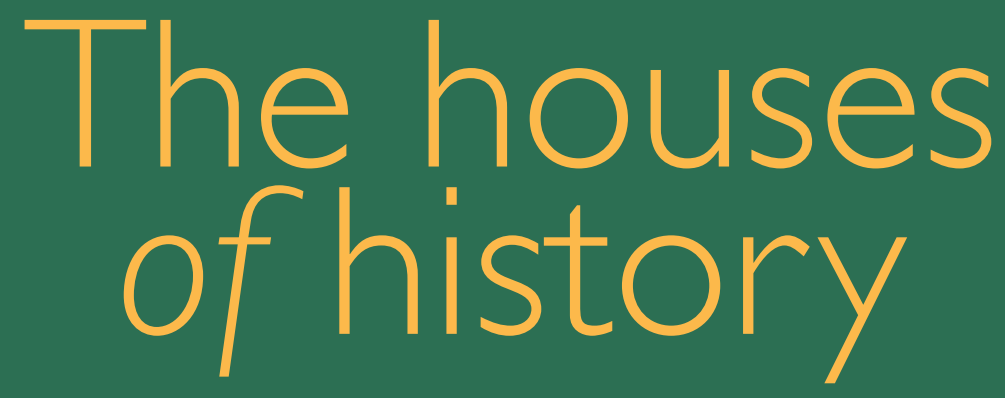

A critical reader in history and theory, second edition
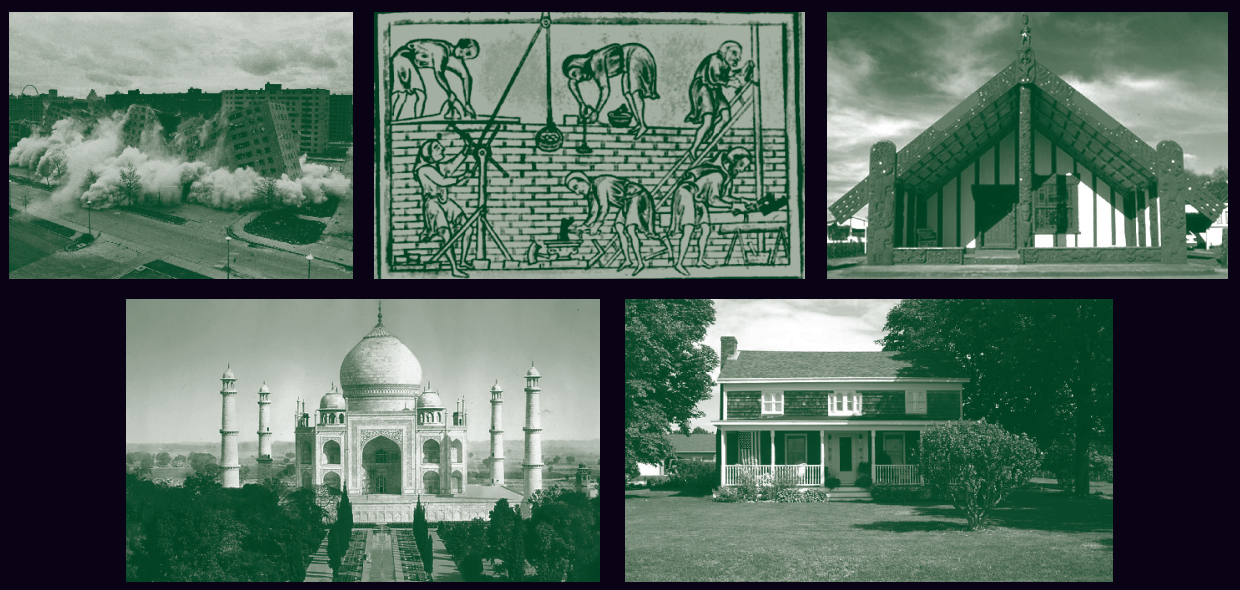

Anna Green and Kathleen Troup 


\section{The houses of history}

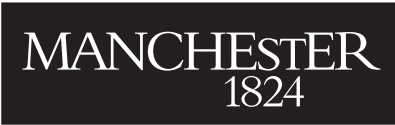

Manchester University Press 
Anna Green and Kathleen Troup - 9781526153708 Downloaded from manchesterhive.com at 04/26/2023 01:40:06PM 


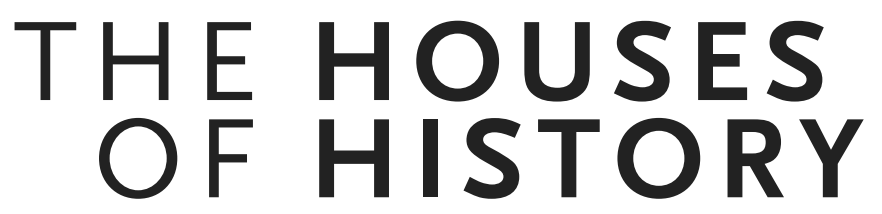

A critical reader

in history and theory, second edition

ANNA GREEN AND KATHLEEN TROUP

Manchester University Press 
Copyright (C) Manchester University Press 1999, 2016

While copyright in the volume as a whole is vested in Manchester University Press, copyright in individual chapters belongs to their respective authors, and no chapter may be reproduced wholly or in part without the express permission in writing of both author and publisher.

First edition published 1999 by Manchester University Press

This edition published 2016 by Manchester University Press Altrincham Street, Manchester M1 7JA

www.manchesteruniversitypress.co.uk

British Library Cataloguing-in-Publication Data

A catalogue record for this book is available from the British Library

Library of Congress Cataloging-in-Publication Data applied for

ISBN 9780719096204 hardback

ISBN 9780719096211 paperback

Typeset in Scala and Stone Serif by

Servis Filmsetting Ltd, Stockport, Cheshire 